\title{
LIBROS
}

\section{Guía de ceremonial religioso en confesiones no católicas} SUBIRATS SORROSAL, Chantal, Síntesis, Madrid, 2016. 180 págs.

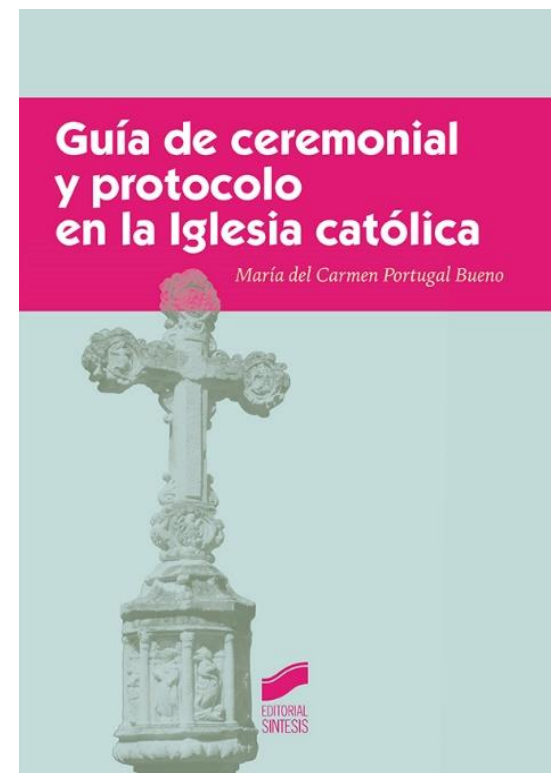

Dolores del Mar Sánchez

UNED

mdmsanchez@der.uned.es

Recepción: 22.11.2016. Revisión: 22.11.2016 Aceptación: 27.12.2016 Publicación 15.01.2017 
Esta obra, inédita en cuanto a su temática, tiene el propósito de servir como marco de referencia para los profesionales del protocolo, para los empresarios que quieran conocer las tradiciones culturales y religiosas de sus interlocutores, y para quienes, por sus inquietudes, deseen conocer los aspectos rituales y protocolarios de las religiones no católicas tratadas (hinduismo, judaísmo, islam, iglesias ortodoxas, iglesias protestantes e iglesias anglicanas). Cada capítulo va introduciéndose gradualmente en el universo de cada confesión, empezando por su origen, continuando por la descripción de sus principales textos sagrados y mostrando la estructura organizativa interna y los títulos de cortesía adecuados en cada caso. A partir de esta base, se construye todo el aparato ceremonial que incluye los ritos cotidianos del creyente, el calendario festivo con la descripción de las principales fiestas, y todas aquellas ceremonias relacionadas con el ciclo vital de los individuos, desde los natalicios hasta la celebración de las honras fúnebres.

Chantal Subirats Sorrosal es Doctora en Historia, investigadora en materia de Ceremonial y profesora en diversas universidades e instituciones, entre ellas, la Universitat Internacional de Catalunya (UIC) y la Universidad Nacional de Educación a Distancia (UNED). Es también colaboradora habitual de las revistas del grupo MPress en materia de ceremonial fúnebre en diferentes culturas y confesiones religiosas. 